\title{
'Maciel' peach tree development grafted on 'Flordaguard' clonal rootstock in different periods
}

\author{
Aline Ramm ${ }^{1 *}$, Márcia Wulff Schuch ${ }^{1}$, Cíntia de Moraes Fagundes ${ }^{2}$, Jacqueline Barcellos da Silva ${ }^{1}$ and Roseane
} Maidana Moreira ${ }^{1}$

${ }^{1}$ Universidade Federal de Pelotas, Programa de Pós Graduação em Agronomia, Fruticultura de Clima Temperado, Departamento de Fitotecnia, Caixa Postal 354, CEP 96010 900, Pelotas, Rio Grande do Sul, Brazil. ${ }^{2}$ Universidade Federal do Paraná, Programa de Pós-graduação em Produção Vegetal, Departamento de Fitotecnia e Fitossanitaríssimo,

\begin{abstract}
The objective of this study was to compare the vegetative and productive aspects and the quality of "Maciel" peach fruits grown on 'Flordaguard' clonal rootstock obtained from mini-cuttings, in different grafting periods (active bud and dormant bud). The experiment was conducted in an orchard located at Centro Agropecuário de Palma, in the county of Capão Leão, by Universidade Federal de Pelotas, RS (UFPel), from 2014/15 to 2015/16. The following variables related to the vegetative aspects were evaluated: canopy volume, trunk diameter, branch diameter, plant height, phenology (initial, full and final flowering), productive aspects, estimated productivity $\left(\mathrm{t}_{\mathrm{h}} \mathrm{a}^{-1}\right)$, production (kg. plant), production effectiveness, fruit diameter and physical-chemical characteristics such as firmness, color, $\mathrm{pH}$, titratable total acidity, soluble solids, soluble solids/ titratable acidity relationship, antioxidant capacity, phenolic compounds and carotenoids. The most recommended grafting method for the 'Maciel' peach tree on 'Flordaguard' rootstock propagated by mini-cuttings is the active bud grafting.
\end{abstract}

Key words: Prunus persica, active bud grafting, dormant bud grafting, mini-cuttings, clonal rootstock.

\section{INTRODUCTION}

Fruit farming has developed new ways to meet the demands of the modern such as climate factors and phytosanitary problems, by adopting new technologies to get quality seedlings for production success and to guarantee return on investment. Peach tree (Prunus persica L. Batch) culture deserves special attention due to recent research advances in cultivar breeding and changes in management practice, pest control, diseases in the seedlings production area and in this culture's propagation methods.

One way to propagate this fruit tree is through canopy cultivar grafting on rootstock originated from seeds. Among the rootstocks used in the South, the 'Flordaguard', which is a hybrid of P.persica $\mathrm{x}$ P. davidiana obtained in Florida, whose need in the cold is of approximately 300 hours, becomes an interesting option for years with climate variations. It is also resistant to root knots nematodes such as Meloidogyne incognita, M. javanica and M. floridensis, and shows good adaptation to the soils in the Pelotas, RS region (Ferguson and Chaparro 2007; Timm et al., 2015; Tomaz et al., 2014).

Among the most used grafts in peach trees in Southern Brazil is the active bud grafting, normally carried out in November-December for allowing the collection of seedlings in a single vegetative cycle. Another viable option is the dormant bud grafting, realized at the end of summer or beginning of winter. This option aims at using rootstocks in which the use of active bud grafting was unsuccessful or the diameter was not adequate enough (Fachinello et al., 2005; Reis et al., 2010). The difference is that the latter requires a longer period for seedling collection, i.e., it requires two vegetative cycles.

Works carried out with peach tree rootstock seedlings production grafted on active and dormant buds showed significant reduction in seedlings collection time, of approximately 12 months. This time reduction was due to their clonal origin and mini-cuttings propagation (Tomaz et al., 2014), and the period normally observed, and verified in various works, is of approximately 14 to 15 months, in rootstock seedlings, when propagated by seeds, under Southern region conditions, according to Fachinello et al. (2005) and Chalfun and Hoffmann (1997). Therefore, it is important to follow the behavior of these plants in the field, to verify any that could favor or limit their development.

So, the objective of this work is to evaluate the behavior of the peach tree 'Maciel' grafted on clonal 'Flordaguard' in different grafting periods, in regards to vegetative and productive aspects and fruit quality.

\section{MATERIALS AND METHODS}

The experiment was conducted in an orchard located at Centro Agropecuário da Palma, in the county of Capão Leão, in Pelotas, RS (31'48'S, 52³0'W and altitude of $60 \mathrm{~m}$ ). According to Köppen and Geiger (1928), the climate in the region is classified as $\mathrm{Cfa}$, temperate, humid and with hot summers. Annual average temperature in the first growing season was $18.74{ }^{\circ} \mathrm{C}$, and in the second $18.5^{\circ} \mathrm{C}$, emphasizing that there was a difference in the month of August $2014 / 15$, when average temperatures were $13.9^{\circ} \mathrm{C}$ and $2015 / 16,17.7^{\circ} \mathrm{C}$. Cumulative rainfall was $1,778.6 \mathrm{~mm}$ in 2014/15, with a total of 1.841,49 mm (Estação Agroclimatológica de Pelotas, 2016). Local soil for the experiment belongs to the Camaquã mapping unit, being moderately deep with average texture in horizon $\mathrm{A}$ and clayey in 
horizon B, classified as red yellow argisol (Embrapa 2006).

Three-year-old 'Maciel' peach trees were used, with spacing of $5 \mathrm{~cm}$ between planting lines and $1.4 \mathrm{~cm}$ between plants, and conducted in "Y". This study was composed by a bi-factorial design including grafting periods ('Maciel' on Flordguard rootstock with active bud grafting; 'Maciel' on 'Flordaguard' rootstock with dormant bud grafting) and growing seasons (2014/15 e 2015/16). The experimental design was randomized, with complete blocks and four replications per treatment, being each replication constituted of three plants, according to Figure 1.

Vegetative aspects were evaluated with an increase in trunk diameter, average branch thickness, plant height and canopy volume, calculated by the formula:

$\mathrm{V}=[(\mathrm{L} / 2) \times(\mathrm{E} / 2) \times(\mathrm{A}) \times(\pi)] / 3$, according to Rocha et al. (2007). $\mathrm{F}$

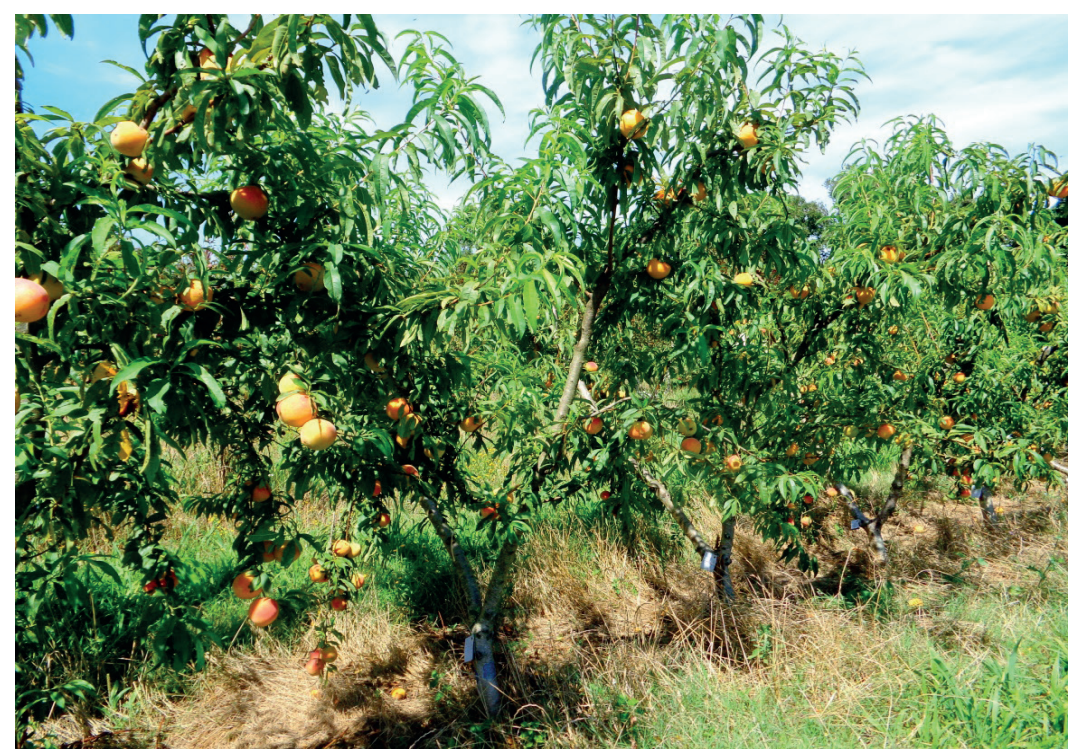

Figure 1. 'Maciel' peach tree.

Source: Aline Ramm, 2015.

The following variables were determined at harvesting: productivity, total production per plant, production effectiveness and average fruit diameter $(\mathrm{mm})$. Productivity and total production/plant were obtained through the total collected fruit weight expressed in tons per hectare and kilograms per plant, respectively. Production efficiency was obtained by the relationship between plant production and canopy volume and trunk section area, expressed in $\mathrm{kg} \mathrm{m} \mathrm{m}^{-3}$ and $\mathrm{kg} \mathrm{cm}^{-2}$, respectively, and cumulated production by the sum of the total production per plant within each year. The diameter was measured in 10 fruit by replication, in the equatorial direction, through digital caliper gauge.

A sub-sample of 20 fruit per replication were submitted to the following physical-chemical analyses: pulp firmness (PF - Newtons) epidermis color $(\Delta \mathrm{E})$, soluble solids (SS - oBrix), titratable acidity (TA $-\%$ of citric acid) and the SS/TA relationship, measured by a manual penetrometer with a $8 \mathrm{~mm}$ pointed tip, colorimeter, digital refractometer and titration neutralization with $\mathrm{NaOH} 0,1 \mathrm{~N}$, respectively. Epidermis color was measured by a Minolta ${ }^{\circledR}$ colorimeter and aperture of $8 \mathrm{~mm}$, in a system registered by the Commission Internationale de I'Eclairage $\mathrm{L}^{*}, \mathrm{a}^{*}$ e $\mathrm{b}^{*}$ (CIELab), using color- spatial coordinates. Readings were realized on the opposite sides of each fruit and, and based on them, color tones values were calculated (angle $h^{\circ}$ ), expressed in degrees, by the formula $h^{\circ}=\tan -1 b^{*} a^{*}-1$.

Total carotenoids were adapted from Talcott and Howard (1999): $2.5 \mathrm{~g}$ of tissue was homogenized with $20 \mathrm{~mL}$ of ethanol solution with $200 \mathrm{mg} \mathrm{L}$ of BHT. After centrifugation fro $20 \mathrm{~min}$ at $2{ }^{\circ} \mathrm{C}$, the supernatant was transferred to a funnel of $50 \mathrm{~mL}$, with the addition of a solvent for the final volume of $50 \mathrm{~mL}$. The solution was transferred by a plastic recipient and $25 \mathrm{~mL}$ of hexane was added to the peach samples. Next, $12.5 \mathrm{~mL}$ of water and nanopure solution were added and agitated vigorously, and the solution was left for 30 minutes at rest to allow for phases separation. The separate phase and the hexane were used. The spectrophotometer was reset using hexane and the readings made at $470 \mathrm{~nm}$. Total carotenoids concentration was calculated from a standard curve built for the $\beta$-carotene and the results expressed in mg equivalent $\beta$-carotene $100 \mathrm{~g}^{-1}$.

For the phenolic compounds, $5 \mathrm{~g}$ of fruit was weighed, with duplicates of each replication, for all treatments, and homogenized in ultra-turrax with $20 \mathrm{~mL}$ of solvent (methanol), and later taken to a Jouan centrifuge, at $5 \mathrm{rpm}$, at $0^{\circ} \mathrm{C}$, for 15 minutes, and supernatant was pipetted to ependorf tube and preserved at $-20^{\circ} \mathrm{C}$, until reading. An aliquot of $50 \mu \mathrm{L}$ of the sample supernatant was diluted in $4 \mathrm{~mL}$ of distilled water, $200 \mu \mathrm{L}$ of methanol and $250 \mu \mathrm{Lof}$ the reagente Folin-Ciocalteau Swain and Hillis (1959) $0.25 \mathrm{~N}$ and reacted for 4 minutes before adding $500 \mu \mathrm{L}$ of $\mathrm{Na} 2 \mathrm{CO} 31 \mathrm{~N}$. Next, the mixes were kept at rest for 2 hours under room temperature and in the dark. A Genesys 10uv spectrophotometer read the samples under an absorbance of $725 \mathrm{~nm}$, in a quartz cuvette. In cases where 
absorbance was higher than 0.6 absorbance units (AU), samples were diluted and re-analyzed. A standard curve for the chlorogenic acid was built and the results expressed in $\mathrm{mg}$ chlorogenic acid equivalent $100 \mathrm{~g}^{-1}$ ).

For antioxidant capacity, $5 \mathrm{~g}$ of the sample were weighed, with duplicates for each replication and then crushed in ultra-turrax with $20 \mathrm{~mL}$ of methanol and centrifuged for 15 minutes at $5 \mathrm{rpm}, 0^{\circ} \mathrm{C}$ in a Jouan refrigerated centrifuge. An aliquot of $10 \mu \mathrm{L}$ from the sample's supernatant was combined with $150 \mu \mathrm{L}$ of methanol and $3.800 \mu \mathrm{L}$ of DPPH solution (2.2-dyfenil-1- picrylhydrazyl) (Brand-Williams et al., 1995). These samples and a "white" (control) reacted for 24 hours to then make a reading in a quartz cuvette, in a Genesys $10 \mathrm{uv}$, spectrometer reset with methanol. Absorbance was of $515 \mathrm{~nm}$, and, when lower than $0.2 \mathrm{UA}$, samples were diluted in methanol and re-analyzed. A standard curve was designed for the 6-hydroxy-2, 5, 7, 8-tetramethylchroman-2-carboxylic acid, and the results were expressed in $\mu \mathrm{g}$ trolox equivalent. $\left.\mathrm{g}^{-1}\right)$.

Data were analyzed in regards to normality by the Shapiro Wilk test, homocedasticity by the Hartley test; residues independence by graphic analysis. A transformation $\sqrt{ }(x+1)$. was needed for the $\mathrm{h}^{\circ}$ variables, diameter and productivity. Next, the data were submitted to an analysis of variance $(\mathrm{p} \leq 0.05)$ with the mixed models procedure (PROC MIXED). This method is particularly convenient for this experiment's condition for allowing flexibility for the error covariance matrix model. A linear mixed effects method was established for year (growing season) and grafting periods, as follows:

$y i j k=\mu+b j+\alpha i+y j+(\alpha y) i j+e i j k$, where:

$y \mathrm{ijk}=$ is the value observed in the $\mathrm{i}$-th year (growing season) and $\mathrm{j}$-th grafting period;

$\mu=$ is the general mean for the response variable;

$\mathrm{b}=$ is the block effect;

$\alpha i=$ is the fixed effect of the $i$-th year (growing season);

$y j=$ is the fixed effect of the $j$-th grafting period;

$(\alpha y) i j=$ is the interaction fixed effect of the it year (growing season ) with the $\mathrm{j}$-th grafting periods;

eijk = random experimental error.

In regards to significance, year effects (growing season) and grafting periods were analyzed by the $t$ test $(\mathrm{p} \leq 0.05)$.

\section{RESULTS AND DISCUSSION}

Canopy volume (CV) growth showed higher values in 2015/16, as expected, and, in the same year, grafted plants with active bud showed greater canopy growth (Table 1). Branch average thickness (BAT), showed greater growth for plants with active bud, when the two crops were compared.

Table 1. Canopy volume (m3), branch average thickness (m) of 'Maciel' peach tree grafted on 'Flordaguard' with dormant bud and active bud, in different growing season (2014/15, 2015/16). Capão do Leão, RS, Brazil. 2016.

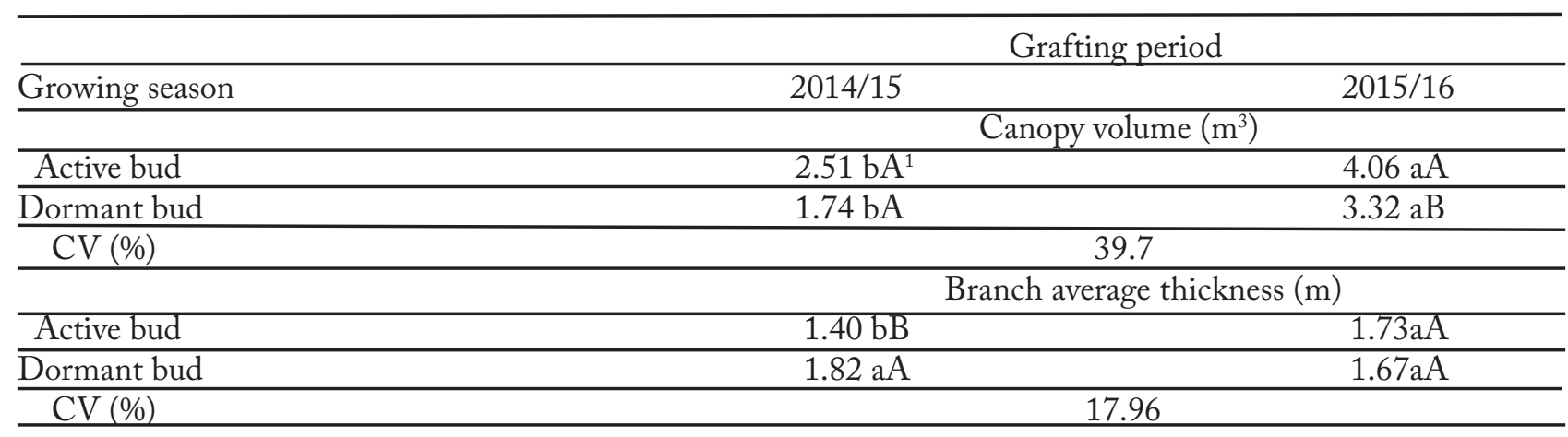

${ }^{1}$ Means followed by the same lowercase letter in the line, comparing growing seasons and uppercase letters in the column within each grafting period shoe no difference among them by the t test $(p \leq 0.05)$.

This result was also found by Souza et al. (2017), working with grafting periods (of active and dormant buds) in peach seedlings cv. Maciel, in the first development year, and observed greater BAT growth in plants from active bud grafting. However, during the 2014/15 crop, plants from dormant bud expresses greater development.

Plant height variable showed no interaction effect $(\mathrm{F}=3.07, p=0.08)$, year effect $(\mathrm{F}=0.57 p=0.45)$, and grafting period ( $\mathrm{F}=0.00 p=0.94)$. Trunk diameter, according to Rossi et al. (2004), may be used to estimate plants' production potential; however, this variable also showed no interaction $(\mathrm{F}=2.27, p=0.13)$, year $(\mathrm{F}=0.50 p=0.48)$ and grafting period $(\mathrm{F}=0.00, p=0.98)$ effects. These results show that each year will have a different influence on pant height.

Production efficiency, productivity and production per plant were higher in 2015/16 (Table 2). Productivity results (6.80 and 15.16 t.ha-1) and cumulated production of 5.10 and $11.37 \mathrm{~kg} / \mathrm{plant}$ were similar and even superior to those 
mentioned by Comiotto et al. (2013), who researched 'Maciel' on 'Flordaguard' via seed, and found productivity levels of 3.45 and 7.17 t.ha- 1 and cumulated production of 2.59 and $5.38 \mathrm{~kg} / \mathrm{plant}$.

Table 2. Production efficiency ( $\mathrm{cm}-2)$, productivity $\left(\mathrm{t} \cdot \mathrm{ha}^{-1}\right)$, cumulated production ( $\left.\mathrm{kg} / \mathrm{plant}\right)$, and diameter $(\mathrm{mm})$ of 'Maciel' peach fruit during the 2014/15, 2015/16 growing seasons. Capão do Leão, RS, Brazil. 2016.

\begin{tabular}{lccc}
\hline & & Growing seasons & \\
\cline { 3 - 4 } & $2014 / 15$ & $2015 / 16$ & CV $(\%)$ \\
\hline Production efficiency $\left(\mathrm{cm}^{-2}\right)$ & $0.10^{*}$ & 0.19 & 58.9 \\
Productivity $\left(\right.$ tha $\left.^{-1}\right)$ & $7.29^{*}$ & 16.24 & 28.2 \\
Cumulated production $(\mathrm{kg} /$ planta) & $5.10^{*}$ & 11.37 & 27.6 \\
Fruit diameter $(\mathrm{mm})$ & $64.83^{*}$ & 23.79 & 7.66 \\
\hline
\end{tabular}

${ }^{*}$ Significant by the $\mathrm{t}$ test $(\mathrm{p} \leq 0.05)$ for each growing season.

It is important to emphasize that, in the previous year, fruit showed larger diameters, i.e., in the last year, there was greater production; however, smaller fruit. The literature suggests that each rootstock need for cold may affect canopy cultivar physiology, modifying the events occurred since the beginning of floral induction, and fruit quality attributes such as minerals concentration, cells number and size, fruit form and size, maturation time and conservation (Bangerth 2008).

In regards to the physical-chemical variables, the $\mathrm{pH}$ was higher for the dormant bud grafting period in the crop of 2015/16, and titratable acidity (TA) results were the highest in 2015/16 (0.55 and 0.45) for the different periods. In the same growing season, active bud plants showed higher TA values $(0.55 \%$ of citric acid) (Table 3$)$. These higher results for the following year may be related to climate factors such as greater occurrence of rain in the second year. Some authors verified higher TA values $(0.70$ and $0.87 \%)$ for 'Maciel' than those found in this work (Torrales et al., 2008).

Table 3. $\mathrm{pH}$, total titratable acidity (TA), pulp firmness (N) means for 'Maciel' peach fruit grafted on 'Flordaguard', with dormant bud and active bud, in different growing seasons (2014/15, 2015/16). Capão do Leão, RS, Brazil. 2016.

\begin{tabular}{|c|c|c|}
\hline \multirow{3}{*}{ Grafting period } & \multicolumn{2}{|c|}{ Growing season } \\
\hline & $2014 / 15$ & $2015 / 16$ \\
\hline & \multicolumn{2}{|c|}{$\overline{\mathrm{pH}}$} \\
\hline Active bud & $3.88 \mathrm{aA}^{1}$ & $3.68 \mathrm{aB}$ \\
\hline Dormant bud & $3.84 \mathrm{Aa}$ & $3.77 \mathrm{aA}$ \\
\hline $\mathrm{CV}(\%)$ & \multicolumn{2}{|c|}{1.32} \\
\hline & \multicolumn{2}{|c|}{ Titratable Acidity (\% citric acid) } \\
\hline Active bud & $0.26 \mathrm{bA}$ & $0.55 \mathrm{aA}$ \\
\hline Dormant bud & $0.27 \mathrm{bA}$ & $0.45 \mathrm{aB}$ \\
\hline CV (\%) & \multicolumn{2}{|c|}{6.06} \\
\hline \multicolumn{3}{|l|}{ Firmness $(\mathrm{N})$} \\
\hline Active bud & $14.51 \mathrm{bA}$ & $23.92 \mathrm{aA}$ \\
\hline Dormant bud & $14.79 \mathrm{bA}$ & $17.92 \mathrm{aB}$ \\
\hline $\mathrm{CV}(\%)$ & \multicolumn{2}{|c|}{11.94} \\
\hline
\end{tabular}

${ }^{1}$ Means followed by the sale lowercase letter in the line comparing growing seasons and uppercase letters in the column within each grafting period, show no difference among them by the $\mathrm{t}$ test $(\mathrm{p} \leq 0.05)$.

Pulp firmness showed no difference between periods in the first growing season; however, the second season produced firmer pulps for active bud grafting, conferring more firmness to the fruit, when the two seasons were compared (Table 3). According to the literature, peach for industry and consumption in natura, as the 'Maciel', need to have good appearance, firm texture and, good level of ripeness (not mushy), which will also contribute to longer shelf life (Crisosto et al., 1995).

The color variable represented by the angle ${ }^{\circ} \mathrm{h}$ showed no statistical significance $(\mathrm{F}=0.50, p=0.4931)$, gross season effect $(\mathrm{F}=3.95, p=0.0702)$, and grafting period effect $(\mathrm{F}=0.99, p=0.3403)$.

SS content and the SS/TA relationship was higher in 2014/15, and showed no interaction for grafting period effect. However, the SS/TA relationship of 44.94 and 18.52 (Table 4) found in the work were higher than the values found by other authors, who verified values of 12.94 and 15.24 for 'Maciel' grafted on 'Flordaguard' (Comiotto et al., 2013). 
Table 4. Soluble solids SS ( ${ }^{\circ}$ Brix), soluble solids/titratable acidity (SS/TA) relationship (SS/AT) in 'Maciel' peach fruit during the 2014/15, 2015/16 growing seasons. Capão do Leão, RS, Brazil. 2016.

\begin{tabular}{lccc}
\hline & \multicolumn{2}{c}{ Growing Season } \\
\cline { 2 - 4 } & $2014 / 15$ & $2015 / 16$ & CV $(\%)$ \\
\hline SS ( ${ }^{\circ}$ Brix $)$ & $12.17^{*}$ & 9.26 & 6.06 \\
SS/AT & $44.94^{*}$ & 18.52 & 9.75 \\
\hline
\end{tabular}

${ }^{*}$ Significant by the $t$ test $(\mathrm{p} \leq 0.05)$ for each growing season.

This SS/TA relationship, also known as maturation index/rate, indicates fruit flavor, since it is the result of a balance between these constituents (Mathias et al., 2008). It was evident that there was a stronger SS/TA relationship during the 2014/15 season, plus other factors, which could also have influenced these results, such as greater occurrence of rain during the second season and the lower presence of low temperatures below $7.2^{\circ} \mathrm{C}$ during the winter.

In regards to the phenolic compounds, higher means were verified in 2014/15; however, they showed no differences among treatments for the periods (Table 5). Antioxidant capacity values showed no difference when the two crops were compared; however, the analysis of the grafting periods showed an increase for active bud plants in 2015/16, $\left(5921.8 \mu \mathrm{g}\right.$ trolox equivalent. $\left.\mathrm{g}^{-1}\right)$.

Table 5. Phenolic compounds, antioxidant activity in 'Maciel' peach grafted on 'Flordaguard' with dormant bud and active bud, in different growing seasons (2014/15, 2015/16). Capão do Leão, RS, Brazil. 2016.

\begin{tabular}{ccc}
\hline & \multicolumn{2}{c}{ Growing season } \\
Grafting period & $2014 / 15$ & $2015 / 16$ \\
\hline & Phenolic compounds (mg chlorogenic acid.100 g-1) \\
\hline Active bud & $285.76 \mathrm{aA}^{1}$ & $117.82 \mathrm{bA}$ \\
Dormant bud & $243.51 \mathrm{aA}$ & $111.64 \mathrm{bA}$ \\
\hline $\mathrm{CV}(\%)$ & \multicolumn{2}{c}{8,43} \\
\hline & Antioxidant activity $(\mu \mathrm{g}$ trolox equivalent.g-1). \\
\hline Active bud & $4528.3 \mathrm{aA}$ & $5921.8 \mathrm{aA}$ \\
Dormant bud & $3720.8 \mathrm{aA}$ & $4354.1 \mathrm{aB}$ \\
\hline $\mathrm{CV}(\%)$ & & 13,55 \\
\hline
\end{tabular}

Compounds concentration may have been affected by environmental factors, as mentioned by some authors, and these contents are increased with crops with low rainfall, which confirms the higher concentration in the first year. However, several factors may be related, such as maturation, cultivation practices, growth stage, harvesting conditions and fruit warehousing process (Soares et al., 2008).

Carotenoids showed some interaction for growth season effect (6.62 and 4.07 of $\bigotimes$-carotene100 $\mathrm{g}^{-1}$ ) (Table 6) and means were higher than those observed by Segantini et al. (2012), which varied between 0.03 and $0.08 \mathrm{mg}$ of 凶-carotene $100 \mathrm{~g}^{-1 .}$ Normally, carotenoids content in peach vary between 0.067 and $6.3 \mathrm{mg}$ of $\bigotimes$-carotene.100 $\mathrm{g}^{-1 .}$. Other works analyzed carotenoids content in the 'Diamante', 'Coral' and 'Xiripá peach cultivars and found 0.4; 0.03 and $0.06 \mathrm{mg}$ of $\bigotimes$-carotene $100 \mathrm{~g}^{-1}$, respectively (Sentanin and Amaya 2007). However, other authors found the following values for the "Diamante" cultivar: $1.6 \mathrm{mg} 100 \mathrm{~g}-1$ and $3.29 \mathrm{mg} 100 \mathrm{~g}^{-1}$. Several factors can influence this substance content such as culture location and climate. Some authors mention that factors such as low rain concentrations may also affect carotenoids content reduction; however, the same was not observed in the referred work (Santos et al., 2013).

Table 6. Carotenoids in the 'Maciel' peach during the 2014/15, 2015/16 growing seasons, Capão do Leão, RS, Brazil. 2016.

\begin{tabular}{lrc}
\hline & \multicolumn{2}{c}{ Growing season } \\
\cline { 2 - 3 } & $2014 / 15$ & $2015 / 16$ \\
\hline Carotenoids $(\mathrm{mg} \otimes$ carotene equivalent.100 $\mathrm{g}-1)$ & $6,62^{*}$ & 4,07 \\
\hline $\mathrm{CV}(\%)$ & & 24,41 \\
\hline${ }^{*}$ Significant by the $\mathrm{t}$ test $(\mathrm{p} \leq 0.05)$.
\end{tabular}


Different grafting periods showed variations in the two crops. It is important to highlight that the plants clonal origin preceded their collection for field planting, what becomes interesting for growers and nursery operators, since it reduces the time for pre-formed seedlings collection, as attested by works. However, these plants development in the fields showed values according to the average in the literature. In addition, higher values were found for some variables, when other works were compared.

\section{CONCLUSION}

The most recommended grafting method for the 'Maciel' peach tree on clonal 'Flordaguard' rootstock propagated by mini-cuttings is the active bud grafting.

\section{ACKNOWLEDGEMENTS}

To the CAPES - Brazilian Federal Agency for the Support and Evaluation of Graduate Education- for granting the scholarships. To FAPERGS - Research Foundation of Rio Grande do Sul- and CNPq - National Council for Scientific and Technological Development for the financial support.

\section{REFERENCES}

Bangerth KF (2008) Possible Interferences of Pre-Harvest Factors with the Storage Behaviour and Quality of Fruit. Acta Horticulturae 796: 19-30.

Brand-Wiliams W, Cuvelier ME and Berset C (1995) Use of a free radical method to evaluate antioxidant activity. Food Science and Technology 28: 25-30.

Chalfun NNJ and Hoffmann A (1997) Propagação do pessegueiro e da ameixeira. Informe Agropecuário 18(189): 23-29.

Comiotto A, Fachinello JC, Hoffmann A, Galarça SP, Machado NP, Prezotto ME and Hass LB (2013) Desenvolvimento, produção e qualidade das frutas de pessegueiros enxertados sobre diferentes porta-enxertos. Semina Ciências Agrárias 34(6): 3553-3562.

Crisosto CH, Mitchell FG and Johnson S (1995) Factors in fresh market stone fruit quality. Postharvest News and Information 6(2): 217-221.

Embrapa (2006) Sistema Brasileiro de Classificação de Solos. Embrapa Solos, Rio de Janeiro, 306 p.

Fachinello JC, Hoffmann A and Nachtigal JC (2005) Propagação de plantas frutíferas. Embrapa, Brasília. DF.

Ferguson J and Chaparro J (2007) Rootstocks for Florida Peaches, Nectarines, and Plums. Horticultural Sciences Department, Institute of Food and Agricultural Sciences. University of Florida, Gainesville, FL 32611 HS1110. http://edis.ifas.ufl.edu/hs366. Accessed 24 fev. 2016.

Köppen W and Geiger R (1928). Klimate der Erde. Verlag Justus Perthes, Gotha.

Mathias C, Mayer AN, Mattiuz B and Pereira FM (2008) Efeito de porta-enxertos e espaçamentos entre plantas na qualidade de pêssegos 'Aurora-1' Revista Brasileira de Fruticultura 30(1): 165-170.

Reis JMR, Chalfun NNJ and Reis MA (2010) Métodos de enxertia e ambientes na produção de mudas de pessegueiro cv. 'Diamante'. Pesquisa Agropecuária Tropical, 40(2): 200-205.

Rocha MS, Bianchi VJ, Fachinello JC, Schmitz JD, Pasa MDS and Silva JB (2007) Comportamento agronômico inicial da cv. Chimarrita enxertada em cinco porta-enxertos de pessegueiro. Revista Brasileira de Fruticultura 29(3): 583-588.

Rossi A, Fachinello JC, Rufato L, Parisotto E, Picolotto L and Kruger LR (2004) Comportamento do pessegueiro 'Granada' sobre diferentes porta-enxertos. Revista Brasileira de Fruticultura 26(3): 446-449. 
Santos CM, De Abreu CMP, Freire J, Mesquita JM and Corrêa AD (2013) Atividade antioxidante de frutos de quatro cultivares de pessegueiro. Revista Brasileira de Fruticultura 35(2): 339-344.

Swain T and Hillis WE (1959) The phenolic constituents of Prunus domestica I.- The quantitative analysis of phenolic constituents. Journal of Science and Food Agriculture 10:63-68.

Segantini DM, Sarita L, Lima GPP, Costa SM and Ramos ARP (2012) Caracterização da polpa de pêssegos produzidos em são Manuel-SP. Ciência Rural 42(1): 52-57.

Sentanin MA and Amaya DBR (2007) Teores de carotenoides em mamão e pêssego determinados por cromatografia líquida de alta eficiência. Ciência e Tecnologia de Alimentos 27(1): 13-19.

Soares M, Welter L, Kuskoski EM, Gonzaga L and Fett R. (2008) Compostos fenólicos e atividade antioxidante da casca de uvas Niágara e Isabel. Revista Brasileira de Fruticultura 30(1): 59-64.

Souza ALK, Schuch MW, Camargo SS, Pereira RR, Souza EL and Pasa MS (2017) Does propagation method affect the field performance of peach trees? Semina: Ciências Agrárias 38(4): 2815-2822.

Talcott TS and Howard RL (1999) Phenolic autoxidation is responsible for color degradation in processed carrot puree. Journal of Agriculture and Food Chemistry 47: 2109-2115.

Timm CRF, Schuch MW, Tomaz ZFP and Mayer NMA (2015) Enraizamento de miniestacas a partir de ramos herbáceos de porta-enxertos de pessegueiro, em diferentes substratos. Revista Inova Ciência \& Tecnologia 1: 18-22.

Tomaz ZFP, Schuch MW, Peil RM N and Timm CRF (2014) Produção de mudas de pessegueiro via enxertia de gema ativa e dormente em sistema de cultivo sem solo. Revista Brasileira de Fruticultura 36(4): 1002-1008.

Toralles R, Vendruscolo JL, Malgarim BM, Cantilhano RF, Schunemann AP and Antunes PL (2008) Características físicas e químicas de cultivares brasileiras de pêssegos em duas safras. Revista Brasileira Agrociência 14(2): 27-338.

Universidade Federal de Pelotas. Estação Agroclimatológica. http://www.ufpel.edu.br/faem/agrometeorologia/ normais.htm. Acessed 28 dez. 2015.

Received: May 16, 2017.

Accepted: July 10, 2017.

Published: September 04, 2017. 